\title{
Disease Progress, Yield Loss, and Control of Xanthomonas fragariae on Strawberry Plants
}

\author{
P. D. Roberts, Department of Plant Pathology, and R. D. Berger, University of Florida, Gainesville, 32611; \\ J. B. Jones, University of Florida, Gulf Coast Research and Education Center (GCREC), Bradenton, 34203; \\ C. K. Chandler, GCREC, Dover, 33527; and R. E. Stall, University of Florida, Gainesville
}

\begin{abstract}
Roberts, P. D., Berger, R. D., Jones, J. B., Chandler, C. K., and Stall, R. E. 1997. Disease progress, yield loss, and control of Xanthomonas fragariae on strawberry plants. Plant Dis. 81:917921.

The progress of angular leaf spot, caused by the bacterium Xanthomonas fragariae, was examined in field plots of strawberry in the 1994 and 1995 seasons. Disease severity increased intermittently to maxima of circa $25 \%$ in 1994 and $15 \%$ in 1995. Angular leaf spot reduced marketable yield $8.6 \%$ in 1994 and $7.7 \%$ in 1995, despite differences in disease severity and base marketable yields for the two seasons. Minimal spread of the pathogen occurred from field plots with inoculated plants to plots with non-inoculated plants. A mixture of cupric hydroxide plus mancozeb was applied at the label rate $(1 \times)$ at 7 - to 14 -day intervals and at a reduced rate $(0.1 \times)$ at 2- to 4-day intervals. The bactericidal mixture at the $1 \times$ rate significantly decreased disease, but this mixture was phytotoxic; both plant size and yield were reduced. The $0.1 \times$ rate was nonphytotoxic and it reduced disease severity in both years and increased yield in 1994. Lesions of angular leaf spot were detected on strawberry transplants imported from nurseries in Canada and northern United States in both 1993 and 1994. X. fragariae was isolated from those lesions.
\end{abstract}

Additional keywords: angular leaf spot of strawberry, Fragaria

Angular leaf spot of strawberry (Fragaria $\times$ ananassa Duchesne), caused by the bacterium Xanthomonas fragariae, was first reported from Minnesota in 1960 (15). The disease has been found in many regions of strawberry production throughout the world. Dissemination of the bacterium occurs via the transportation of infected plants $(4,18,21)$. Translucent lesions on leaves and calyxes, when viewed with transmitted light, are diagnostic symptoms for this disease (18). In California, a vascular collapse of the plant from systemic colonization by the bacterium has been described (10).

The epidemiology of angular leaf spot is unknown for fields in Florida where strawberry production is an annual crop. Most transplants are obtained each season from nurseries in Canada and northern United States; few transplants are produced in Florida. Angular leaf spot has been found sporadically in Floridian nurseries, but the disease was not always found in fruiting fields in which locally grown transplants

Corresponding author: R. D. Berger

E-mail: rdb@gnv.ifas.ufl.edu

Florida Agriculture Experiment Station Journal Series Paper R-05122.

Accepted for publication 25 April 1997.

Publication no. D-1997-0530-01R

(C) 1997 The American Phytopathological Society were used (11). The disease also was widespread in fields planted to transplants that originated from nurseries in California (11). In Minnesota, Kennedy and King (16) determined that $X$. fragariae overwintered in plant debris and caused disease symptoms on plants the next year. The bacterium did not survive free in the soil nor were any naturally occurring hosts identified in host-range studies. In Florida, $X$. fragariae must oversummer on plant refuse for it to serve as an inoculum source. Since the optimal temperature for growth of $X$. fragariae is $\approx 20^{\circ} \mathrm{C}$ and the maximum is less than $32^{\circ} \mathrm{C}$, this bacterium would not grow well at the temperatures that normally occur in Florida during the summer. However, $X$. fragariae survived on summer-nursery plants in the field in Florida, although at very low populations (23).

The effect of angular leaf spot on yield is unknown. Howard (11) credited some yield losses to angular leaf spot in fields in Florida, but the losses were not quantified. In Wisconsin, a yield loss of 75 to $80 \%$ was attributed to the disease (5). However, the production in northern United States is a perennial, matted-row system which differs significantly from the annual system used in Florida. Additional losses occur from infections of the calyx, in which the sepals become brown and dry and the fruit is then unmarketable because of its unattractive appearance $(5,19)$.

Chemical control of bacterial diseases on plants is difficult. Although the antibi- otics streptomycin and oxytetracycline were shown to be effective against $X$. fragariae in vivo (1), these antibiotics have limited effectiveness in the field over time since they weather poorly and the bacteria may mutate to form resistant populations (26). Additionally, these antibiotics are not registered for use on this crop. Copper compounds also are used to control bacterial diseases $(13,14)$. For control of bacterial spot of tomato and pepper caused by $X$. campestris pv. vesicatoria, the efficacy of cupric hydroxide was increased by mixing it with mancozeb $(2,20)$. The application of copper compounds to strawberry plants is confounded in that copper can be phytotoxic to strawberry plants (12). For fungal diseases of several crops, a spray schedule with a reduced rate of fungicide applied at frequent intervals as a protectant effectively slowed the rate of the epidemics $(3,6-8,22,27)$. The frequent sprays maintained adequate levels of fungicide and protected new plant growth that emerged between applications (6). Our objectives in this study were to examine several epidemiological aspects of angular leaf spot on strawberry. Specifically, we wanted to determine the amount of spread of the disease, the speed and severity of the epidemics, the effect of angular leaf spot on yield, and to evaluate a program of frequent applications of reduced rates of copper to control angular leaf spot and to avoid phytotoxicity.

\section{MATERIALS AND METHODS}

Survey of farmers' fields and transplant-storage facility. In October 1993, incidence of angular leaf spot was examined in seven strawberry fields near Dover and Plant City, Florida. In each field, 50 plants were selected at random and assessed for symptoms of angular leaf spot within 2- to 4-days after transplanting. Two or three symptomatic leaves from each plant were collected. With a 9-mm-diameter cork borer, a section that contained a lesion and its surrounding tissue was cut from each symptomatic leaf. Each sample was macerated in $200 \mathrm{ml}$ of sterile water. A loopful of the suspension was streaked onto Wilbrink's medium (WB; 17) and incubated at $24^{\circ} \mathrm{C}$ for 3 to 5 days. Colonies of $X$. fragariae were identified by their pale yellow color and mucoid morphology. Pathogenicity of the isolated strains on Sweet Charlie strawberry plants confirmed 
identification of the strains as $X$. fragariae (23). In 1994, plants were sampled from boxes shipped from northern producers while they were in a cold-storage facility in Dover, Florida. This sampling technique was to ensure that, if $X$. fragariae was found, the source of the bacterium would be clearly identified as infected transplants rather than any chance contamination after transplanting. Seven groups of plants, comprised of four cultivars from six northern growers, were sampled. Three boxes were selected at random within a shipment and 20 plants were removed from each box. The plants were examined for symptoms of angular leaf spot, and attempts to isolate the pathogen from the characteristic lesions was by the method described above.

Preparation of inoculum. Three strains of X. fragariae (Xf113, Xf103, and $X f 1425)$ were used to inoculate plants used in field plots. Strains Xf113 and Xf103 were isolated from infected plants at the Gulf Coast Research and Education Center (GCREC-Dover), and Xf1425 was obtained from Dr. A. Chase (Central Florida Research and Education Center, Apopka, FL). The bacterial strains were cultured on WB at $24^{\circ} \mathrm{C}$ and long-term storage was at $-70^{\circ} \mathrm{C}$ in $15 \%$ glycerol (9). The sensitivity of the strains to copper was tested by growth on nutrient agar amended with $\mathrm{CuSO}_{4}$ (25). Three days prior to scheduled inoculation, each of the strains was streaked to 10 plates of WB. Bacterial cells were collected from plates, suspended in
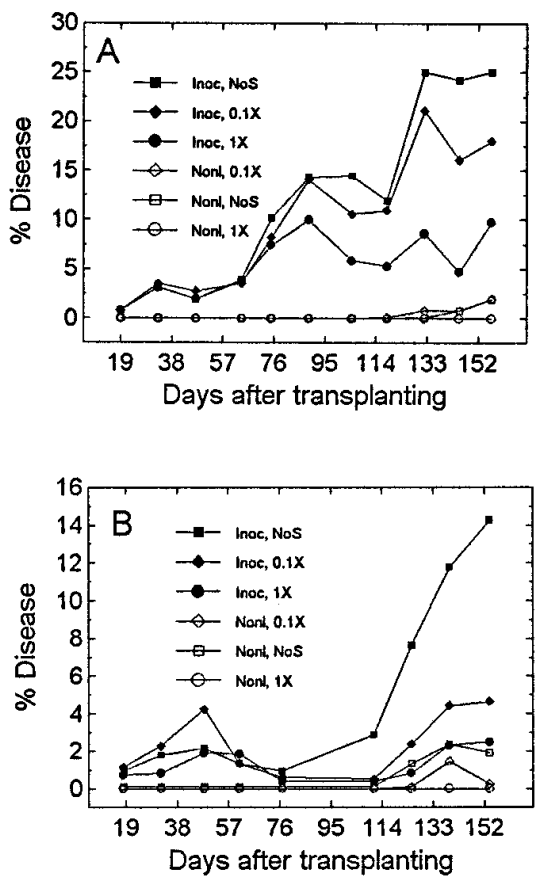

Fig. 1. Disease progress curves of Xanthomonas fragariae on strawberry in Florida in the 1994 (A) and 1995 (B) seasons. The mean of disease severity for four replicate blocks are plotted against days after transplanting (DAT). sterile $0.01 \mathrm{M} \mathrm{MgSO}_{4} \cdot 7 \mathrm{H}_{2} \mathrm{O}$, and the suspension adjusted to a final concentration of $10^{7} \mathrm{CFU} / \mathrm{ml}$. Equal volumes of each suspension were combined to comprise the inoculum. Plants were inoculated by dipping bundles of 25 plants into the bacterial suspension for $30 \mathrm{sec}$. Control plants were dipped into $0.01 \mathrm{M} \mathrm{MgSO}_{4} \cdot 7 \mathrm{H}_{2} \mathrm{O}$. Plants were incubated in plastic bags for $24 \mathrm{~h}$ at $22^{\circ} \mathrm{C}$.

Field experiments. Field plots were located at GCREC-Dover from October 1993 through March 1994 and repeated the following season. Transplants of Sweet Charlie grown in the summer nursery at GCREC-Dover were used. Raised beds were prepared and fertilized with 10-4-10 N-P-K at a rate of $2241 \mathrm{~kg} \mathrm{ha}^{-1}$ with onefourth broadcast before bed preparation and the remainder banded $5 \mathrm{~cm}$ deep in the bed center. In the second season, a drip irrigation system was installed and $0.84 \mathrm{~kg}$ $\mathrm{ha}^{-1}$ each of $\mathrm{N}$ and $\mathrm{K}$ per day was applied through the drip irrigation system. Soil was fumigated with $98 \%$ methyl bromide and $2 \%$ chloropicrin at $448 \mathrm{~kg} \mathrm{ha}^{-1}$ and beds were immediately covered with $35 \mathrm{~mm}$ black polyethylene mulch.

The experimental design was a randomized complete block in a 2 by 3 factorial design with four replications. The first factor had two levels: plants inoculated with (i) the suspension of strains of $X$. fragariae or (ii) the solution of $\mathrm{MgSO}_{4}$. The three levels of the second factor were: (i) no chemical treatment, (ii) the label rate (1x) of cupric hydroxide (Kocide 101 at $3.6 \mathrm{~kg}$ a.i. $\mathrm{ha}^{-1}$ ) plus mancozeb (Dithane DF at $1.8 \mathrm{~kg}$ a.i. $\mathrm{ha}^{-1}$ ) sprayed at 7- to $14-$ day intervals, and (iii) a reduced rate $(0.1 \times)$ of cupric hydroxide plus mancozeb sprayed at 2- to 4-day intervals.

An individual plot on a bed contained 18 plants arranged in two rows of 9 plants. The beds were spaced on 1.22-m centers, with $30 \mathrm{~cm}$ between rows on a bed and 30 $\mathrm{cm}$ between plants within a row. A fallow area of $3.55 \mathrm{~m}$ separated plots on a bed and a fallow bed $(2.44 \mathrm{~m})$ separated plots in the crosswise direction. Pesticides at labeled rates were applied uniformly to all treatments throughout the season as needed to control insects and fungal diseases. Chemical applications were made by a handheld wand attached to a $\mathrm{CO}_{2}$-charged canister at $40 \mathrm{psi}$; pesticide was applied to runoff. Plants were transplanted on 15 October 1993 and on 20 October 1994. Overhead sprinkler irrigation was applied 7 to $8 \mathrm{~h}$ daily for 10 to 14 days to establish the transplants. Overhead irrigation also was applied throughout both seasons as needed to maintain good soil moisture and to facilitate dispersal of bacterial inoculum. Drip irrigation was installed in the summer of 1994 at GCREC-Dover and was used as supplemental irrigation in 1995.

Visual estimates of severity of angular leaf spot were made at 2-week intervals. Severity was expressed as percent leaf area diseased for the entire plant for each of six plants located in the center of each plot. Progress curves of severity were plotted as the mean of replicate treatments versus time. Area under the disease progress curve (AUDPC; 24) was calculated for each plot and used in statistical analysis. Statistical analysis was performed by orthogonal contrasts using PC-SAS (SAS Institute, Inc., Cary, NC).

In both seasons, fruit were harvested at 2- to 4-day intervals from initial bearing in December through 30 March. Fruit were graded as (i) marketable, (ii) culls, or (iii) non-marketable due to damage by fungi; i.e., Colletotrichum spp., Botrytis cinerea, or Phomopsis obscurans. Marketable fruit were those free of rot, not misshapen, and greater than $10 \mathrm{~g}$ in weight. Culls were fruit non-marketable due to physical imperfections such as small size (less than 10 g), damage by insects, or undesirable shape. The weight in grams for each category was recorded for individual plots. Statistical analysis of the weight of fruit in each category was performed using orthogonal contrasts.

\section{RESULTS}

Incidence of angular leafspot on transplants. In 1993, X. fragariae was isolated from symptomatic strawberry plants in six of seven fields. In 1994, three of the seven shipments of transplants sampled from the cold-storage facility contained plants with symptoms of angular leaf spot. In one of these shipments, plants with symptoms of angular leaf spot were found in all of the boxes sampled. Bacteria characteristic of $X$. fragariae were isolated from all plants with lesions of angular leaf spot, and pathogenicity of these strains was confirmed by inoculation onto strawberry plants in the greenhouse.

Disease progress in field plots. The locally grown transplants had no visible symptoms of angular leaf spot at planting in either 1994 or 1995. From the inoculation with $X$. fragariae at the time of transplanting, the first symptoms appeared about two weeks after planting. In 1994, the severity of angular leaf spot on inoculated plants that did not receive a bactericidal spray increased for 89 days after transplanting (DAT), then decreased until 118 DAT, then increased again to $25 \%$ severity by 132 DAT, with little subsequent change to the end of the season (Fig. 1A). In 1995, the epidemic on non-sprayed plants inoculated with the bacteria initially increased by 48 DAT, then decreased until 77 DAT, and then increased again and reached $15 \%$ severity by 154 DAT (Fig. 1B). In both 1994 and 1995, the disease on inoculated plants sprayed with either the $1 \times$ or $0.1 \times$ rate of cupric hydroxide plus mancozeb followed similar disease progress, except the amount of disease was much reduced for these latter two treatments. In contrast to the epidemic on the 
inoculated plants, the onset of the epidemic on the non-inoculated plants was greatly delayed in both years; that is, the initial disease observed on these plants was at 118 DAT in 1994 and at 125 DAT in 1995. The non-inoculated, non-sprayed plants had very little disease ( 0 to $2.25 \%$ severity) by the end of the season. Non-inoculated plants sprayed with the $1 \times$ rate of the bactericidal mixture did not have disease in either year. The disease on those noninoculated plants that received the sprays at the $0.1 \times$ rate of the mixture had a low level of disease similar to the that on noninoculated, non-sprayed plants.

For epidemic intensity as determined by AUDPC, non-inoculated plants in both 1994 and 1995 had significantly $(P=$ $0.0001)$ less disease than plants inoculated with $X$. fragariae (Fig. 2). Comparison of spray treatments with AUDPC could only be done realistically for angular leaf spot that developed on inoculated plants, since only tardive, mild epidemics developed on non-inoculated plants. Inoculated plants sprayed with the $1 \times$ rate of cupric hydroxide and mancozeb had significantly $(P=$ 0.0004 in $1994, P=0.0001$ in 1995) lower
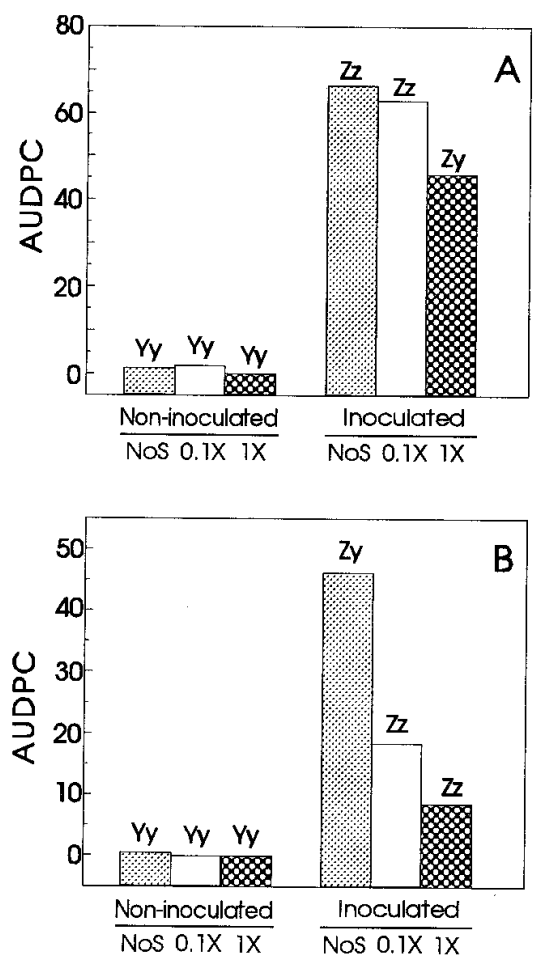

Fig. 2. Area under the disease progress curve (AUDPC) of Xanthomonas fragariae on strawberry in the 1994 (A) and 1995 (B) seasons, and the effect of applications of cupric hydroxide plus mancozeb at the $1 \times$ rate applied at 14-day intervals, $0.1 \times(10 \%)$ rate of the chemical combination applied at 2- to 4-day intervals, or no spray (NoS). Statistical analysis was by orthogonal contrasts as follows: $\mathrm{Y}, \mathrm{Z}=$ significant difference $(P=0.05)$ within the first factor of inoculated versus non-inoculated plants; $y, z$ $=$ significant difference $(P=0.05)$ within the second factor of the spray treatments.
AUDPCs compared to the non-sprayed treatments in both years. Compared to nonsprayed plants, the plants sprayed with the $0.1 \times$ rate of the bactericidal mixture had a lower AUDPC in $1994(P=0.17)$ and a significant $(P=0.0001)$ reduction of AUDPC in 1995.

Yields and yield loss. The total yield (marketable, cull, and fungal diseased fruit) in 1994 averaged across all treatments was $9.38 \mathrm{~kg} \mathrm{ha}^{-1}$. In 1995, the total yield was $3 \%$ lower $\left(9.1 \mathrm{~kg} \mathrm{ha}^{-1}\right)$. The average marketable yield in 1994 was $8.0 \mathrm{~kg}$ $\mathrm{ha}^{-1}$, compared to $6.8 \mathrm{~kg} \mathrm{ha}^{-1}$ for 1995 . The greater percentage decrease in marketable fruit for 1995 was from a threefold increase in loss to fungal diseased fruit $(0.4$ $\mathrm{kg} \mathrm{ha}{ }^{-1}$ for 1994 versus $1.3 \mathrm{~kg} \mathrm{ha}^{-1}$ for 1995). No consistent reduction in fungaldiseased fruit was found in either year for plants sprayed with cupric hydroxide plus mancozeb, compared to the non-sprayed control. Plants that had been inoculated with $X$. fragariae had losses to fungal rots similar to those of non-inoculated plants. The weight of cull fruit was approximately $1 \mathrm{~kg} \mathrm{ha}^{-1}$ for each of the six treatments in each year.

In 1994, the marketable yield for plants inoculated with $X$. fragariae averaged 7.53 $\mathrm{kg} \mathrm{ha}^{-1}$, compared to $8.54 \mathrm{~kg} \mathrm{ha}^{-1}$ for noninoculated plants. In 1995, the average marketable yields for inoculated and non-
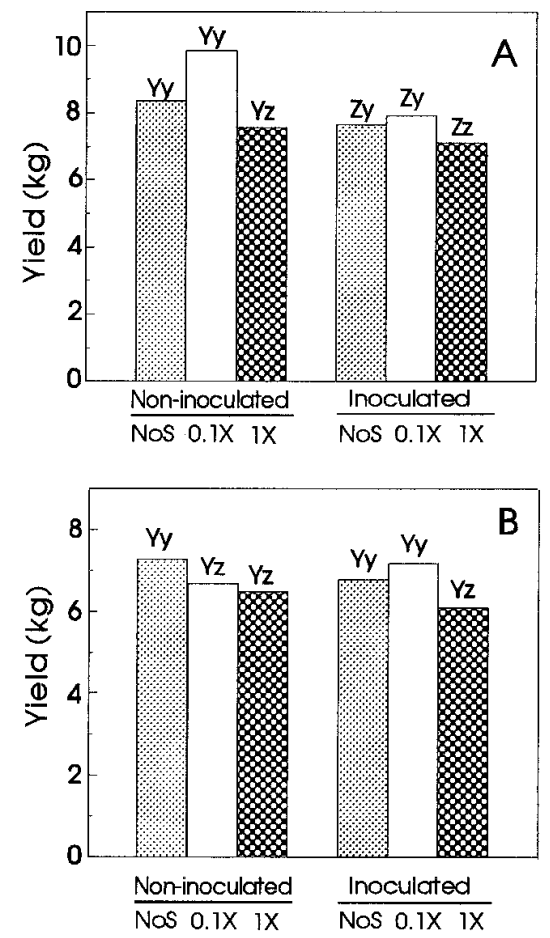

Fig. 3. The marketable yield $\left(\mathrm{kg} \mathrm{ha}^{-1}\right)$ of strawberry in Florida in the 1994 (A) and 1995 (B) seasons. Statistical analysis was by orthogonal contrast as follows: $\mathrm{Y}, \mathrm{Z}=$ significant difference $(P=0.05)$ within the first factor of inoculated vs. non-inoculated plants; $y, z=$ significant difference $(P=0.05)$ within the second factor of the spray treatments. inoculated plants were similar (6.76 versus $6.86 \mathrm{~kg} \mathrm{ha}^{-1}$ ).

The two spray treatments had a substantial effect on yield (Fig. 3). In 1994, sprays of the $0.1 \times$ rate of the bactericidal mixture to non-inoculated plants seemed to have a tonic effect, as marketable yield was increased $15.5 \%$ over the non-sprayed plants (9.7 versus $8.2 \mathrm{~kg} \mathrm{ha}^{-1}$ ). In 1995, a slight positive effect on yield for this spray only occurred for the inoculated plants. In both years, the $1 \times$ rate of the spray mixture resulted in a decrease in marketable yield of 8 to $11 \%$ compared to the non-sprayed plants, whether they had been inoculated with $X$. fragariae or not. Because of the sometimes apparent tonic effect from the $0.1 \times$ spray and the decrease in yield from phytotoxicity to the $1 \times$ spray, the theoretical yield losses to angular leaf spot were calculated only for the inoculated and noninoculated plants that had not received the bactericidal sprays. Marketable yields on non-sprayed plants inoculated with $X$. $\mathrm{fra}$ gariae were reduced $8.6 \%(P=0.005)$ in 1994 and $7.7 \%(P=0.04)$ in 1995 compared to yields on non-sprayed, noninoculated plants (Fig. 4). Total yields (marketable, cull, and fungal diseased fruit) for non-sprayed, inoculated plants were reduced by angular leaf spot $7.4 \%$ in 1994 and $4.8 \%$ in 1995.

\section{DISCUSSION}

Yield of strawberry fruit was reduced in both the 1994 and 1995 seasons due to angular leaf spot. The $\approx 8 \%$ loss determined in these studies is much lower than the 75 to $80 \%$ loss estimated by Epstein (5) in a fruit production field in Wisconsin. Production of strawberries in northern regions of the United States is usually a perennial system, and the age of the plants was not given in the report. The loss in

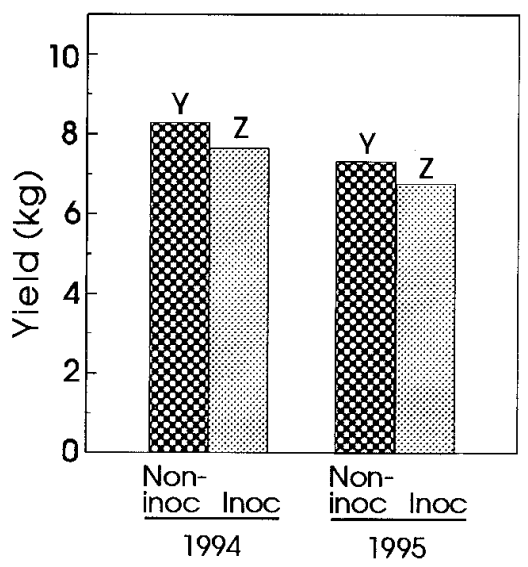

Fig. 4. The average marketable yield $\left(\mathrm{kg} \mathrm{ha}^{-1}\right)$ on non-sprayed strawberry plants which were inoculated with Xanthomonas fragariae (Inoc) or not inoculated (Non-inoc) for the 1994 and 1995 seasons. Yield was the average for four replications for marketable fruit only. Different letters $(\mathrm{Y}, \mathrm{Z})$ represent significant difference at $P=0.05$. 
Wisconsin was in one field on the cultivar 'Sparkle', a variety which is not grown commercially in Florida. Howard (11) also reported nonquantified yield losses to angular leaf spot in Florida, but on cultivars that are no longer in commercial production. In our studies, the average yield losses observed in both years were very similar despite the differences in the disease levels and the base marketable yields between the two seasons. In 1995, the maximum disease severity was $40 \%$ less (14\% versus $25 \%)$ than that estimated in 1994; however, the loss in marketable yield was similar. The $\approx 8 \%$ reduction in yield observed in 1994 or 1995 represents an estimated loss of $2435 \mathrm{~kg}$ of fruit per hectare. Strawberry fruit has a very high cash value, and a decrease in revenue of $8 \%$ for the strawberry crop represents a significant economic loss to producers.

Strawberry producers in Florida currently try to control angular leaf spot by application of copper compounds. An understanding of the epidemiology of angular leaf spot is necessary to determine the effectiveness and practicability of any control method. The survey of farmers' fields and the cold-storage facility established that transplants arrive from northern nurseries infected with $X$. fragariae. Therefore, the initial step to control angular leaf spot in commercial fields would be to reduce or eliminate the pathogen on the transplants. Because of the findings reported here, growers in Florida have since rejected several shipments of strawberry transplants that contained plants with obvious symptoms of angular leaf spot.

In the field, the spread of $X$. fragariae from experimental plots with inoculated plants to plots with non-inoculated plants about $3 \mathrm{~m}$ distant must have been minimal, as the disease appeared late in the season (about 4 months after transplanting) on these latter plots and the maximum severity was only about $2 \%$. Most non-inoculated plants remained free of angular leaf spot. In these plots, if inoculum had been present from another source such as infested debris in the soil or an alternate host, the disease on the non-inoculated plants would have been more general in the plots and likely would have appeared earlier. The disease that eventually occurred on some non-inoculated plants probably originated from inoculum that was inadvertently transported among plots during the multiple harvests and disease assessments. Thus, the early occurrence, high incidence, and high prevalence (among growers) of plants with angular leaf spot in commercial fields likely occurred from inoculum already present in high incidence on the transplants.

Progress of angular leaf spot developed similar to that of polycyclic pathogens described on other crops (27). A decrease in disease severity was seen about midway through the season in 1994. This reduction, or anti-epidemic, was due to growth by strawberry plants which diluted the amount of diseased area relative to the total leaf area. The dilution effect of new, healthy plant tissue on the proportion of disease was described by van der Plank (27). In 1995, a negative infection rate was calculated very early in the epidemic. This was because the symptoms of the disease almost disappeared from the field as the affected leaves died and were lost and as new, healthy leaves emerged and were added to the canopy. The slight difference in disease progress between the two seasons did not appear to be from differences in rainfall, since mean rainfall was approximately the same in both years (data not shown). The appearance of new disease in either year could not be correlated to earlier, specific rain events. Mean temperatures also were similar between years; however, the number of days at temperatures below $10^{\circ} \mathrm{C}$ in November and December were much greater in 1993 than in 1994. Overhead irrigation, fog, high humidity, and rain are positive factors in disease development and spread $(5,10,16)$. The trend towards drip irrigation in commercial production fields should have a negative effect on the spread and survival of the bacterium.

Strawberry producers currently apply copper-based compounds to control angular leaf spot, despite the phytotoxicity to plants caused by copper. Application of cupric hydroxide plus mancozeb at the $1 \times$ rate was phytotoxic to strawberry plants. The phytotoxicity symptoms were purpling and yellowing of the leaves, smaller leaves, severe stunting of the plants, and slightly reduced yields. In our tests, $0.1 \times$ rate did not seem to harm plants and the frequent sprays significantly reduced severity of angular leaf spot in 1995, but the reduction of disease in 1994 by sprays was not significant. The protectant application of the bactericidal mixture at the $0.1 \times$ rate on a frequent spray schedule was intended to reduce the total amount of inoculum and to prevent spread of the disease. The approach of frequent sprays of bactericide at reduced concentrations may have potential to control this disease. More studies are needed to evaluate different rates, application intervals, and chemical mixtures to achieve maximum disease control while avoiding serious yield losses. An alternative approach might be to control the disease in the nursery by applications of copper. The loss in yield due to phytotoxicity would not be an issue on nursery plants. The sprays would reduce or eliminate the amount of initial inoculum on transplants and consequently reduce the amount of disease in fruit-production fields.

\section{LITERATURE CITED}

1. Alippi, A. M., Ronco, B. L., and Carranza, M. R. 1989. Angular leaf spot of strawberry, a new disease in Argentina: Comparative control with antibiotics and fungicides. Adv. Hortic. Sci. 3:3-6.

2. Conover, R. A., and Gerhold, N. R. 1981. Mixtures of copper and maneb or mancozeb for control of bacterial spot of tomato and their compatibility to control fungal diseases. Proc. Fla. State Hortic. Soc. 94:154-156.

3. Conway, K. E., Motes, J. E., Bostian, B., Fisher, C. G., and Claypool, P. L. 1987. Cercospora blight development on asparagus fern and effects of fungicides on disease severity and yield. Plant Dis. 71:254-259.

4. Dye, D. W., and Wilkie, J. P. 1973. Angular leafspot of strawberry in New Zealand. N. Z J. Agric. Res. 16:311-314.

5. Epstein, A. H. 1966. Angular leaf spot of strawberry. Plant Dis. Rep. 50:167.

6. Forcelini, C. A., and Berger, R. D. 1995 Management of epidemics of oat crown rust through the control of the initial waves of disease by reduced rates of fungicide. (Abstr.) Phytopathology 85:1172.

7. Fry, W. E. 1975. Integrated effects of polygenic resistance and a protective fungicide on development of potato late blight. Phytopathology 65:908-911.

8. Fry, W. E., Bruck, R. I., and Mundt, C. C. 1979. Retardation of potato late blight epidemics by fungicides with eradicant and protectant properties. Plant Dis. Rep. 63:970974.

9. Hazel, W. J., Civerolo, E. L., and Bean, G. A. 1980. Procedures for growth and inoculation of Xanthomonas fragariae, causal organism of angular leaf spot of strawberry. Plant Dis. 64:178-181.

10. Hildebrand, D. C., Schroth, M. N., and Wilhelm, S. 1967. Systemic invasion of strawberry by Xanthomonas fragariae causing vascular collapse. Phytopathology 57:12601261.

11. Howard, C. M. 1971. Occurrence of strawberry angular leaf spot, Xanthomonas fragariae, in Florida. Plant Dis. Rep. 55:142.

12. Howard, C. M., and Albregts, E. E. 1973. Strawberry. APS Fungic. Nematicide Tests 29:47.

13. Jones, J. B., and Jones, J. P. 1985. The effect of bactericides, tank mixing time and spray schedule on bacterial leaf spot of tomato. Proc. Fla. State Hortic. Soc. 98:244-247.

14. Jones, J. B., Woltz, S. S., Kelly, R. O., and Harris, G. 1991. The role of ionic copper, total copper, and select bactericides on control of bacterial spot of tomato. Proc. Fla. State Hortic. Soc. 104:257-259.

15. Kennedy, B. W., and King, T. H. 1962. Angular leaf spot of strawberry caused by Xanthomonas fragariae sp. nov. Phytopathology 52:873-875.

16. Kennedy, B. W., and King, T. H. 1962. Studies on epidemiology of bacterial angular leaf spot on strawberry. Plant Dis. Rep. 46:360363.

17. Koike, H. 1965. The aluminum-cap method for testing sugarcane varieties against leaf scald disease. Phytopathology 55:317-319.

18. Maas, J. L., ed. 1984. Angular leaf spot Pages 41-42 in: Compendium of strawberry diseases. American Phytopathological Society, St. Paul, MN.

19. Maas, J. L., Pooler, M. R., and Galleta, G. J. 1995. Bacterial angular leafspot disease of strawberry: Present status and prospects for control. Adv. Strawberry Res. 14:18-24.

20. Marco, G. M., and Stall, R. E. 1983. Control of bacterial spot of pepper initiated by strains of Xanthomonas campestris pv. vesicatoria that differ in sensitivity to copper. Plant Dis. 67:779-781.

21. Panagopoulos, C. G., Psallidas, P. G., and Alivizatos, A. S. 1978. A bacterial leafspot of 
strawberry in Greece caused by Xanthomonas fragariae. Phytopathol. Z. 91:33-38.

22. Pataky, J. K., and Lim, S. M. 1981. Efficacy of benomyl for controlling Septoria brown spot of soybeans. Phytopathology 71:438442.

23. Roberts, P. D., Jones, J. B., Chandler, C. K., Stall, R. E., and Berger, R. D. 1996. Survival of Xanthomonas fragariae on strawberry in summer nurseries in Florida detected by specific primers and nested polymerase chain reaction. Plant Dis. 80:1283-1288.

24. Shaner, G., and Finney, R. E. 1977. The effect of nitrogen fertilization on the expression of slow-mildewing resistance in Knox wheat. Phytopathology 67:1051-1056.

25. Stall, R. E., Loschke, D. C., and Jones, J. B. 1986. Linkage of copper resistance and avirulence loci on a self-transmissible plasmid in Xanthomonas campestris pv. vesicatoria. Phytopathology 76:240-243.

26. Stall, R. E., and Thayer, P. L. 1962. Streptomycin resistance of the bacterial spot pathogen and control with streptomycin. Plant Dis. Rep. 16:389-392.

27. van der Plank, J. E. 1963. Plant Diseases: Epidemics and Control. Academic Press, NY. 